\title{
Pelatihan Penerapan Buku SDKI, SLI dan SIKI pada Perawat di Charlie Hospital
}

\author{
N Sukesi $^{1 *}$, Wahyuningsih ${ }^{2}$ \\ 1)2 Program Studi Ilmu Keperawatan \\ Fakultas Keperawatan, Bisnis dan Teknologi Universitas Widya Husada Semarang \\ Jalan Subali Raya No 12 Krapyak Semarang, Jawa Tengah, Indonesia \\ Corresponding Author: N Sukesi, nikensukesi2004@gmail.com
}

\begin{abstract}
Abstrak: Dokumentasi keperawatan merupakan gambaran tindakan yang diberikan perawat kepada pasien dalam asuhan keperawatan. Dokumentasi ini terdiri dari pengkajian, diagnosis keperawatan, intervensi dan evaluasi. Dokumentasi keperawatan harus dievaluasi terkait dengan penerapannya dalam pemberian asuhan keperawatan. Masih ditemukan keragaman dalam merumuskan diagnosis keperawatan karena beragamnya pendidikan keperawatan, pengetahuan perawat, bahkan perbedaan standar acuan yang digunakan. Perawat di Charlie Hospital mempunyai perbedaan latar belakang asal institusi pendidikan yang berbeda. Sehingga diperlukan pelatihan dalam memberikan asuhan keperawatan terutama dalam perumusan diagnosis keperawatan. Tujuan pengabdian ini untuk menambah pengetahuan, ketrampilan serta penerapan buku SDKI, SLKI dan SIKI dalam penyusunan dokumentasi keperawatan. Metode pengabdian ini dengan cara pengumpulan informasi terkait pengetahuan perawat tentang penerapan SDKI, SLKI dan SIKI, pelatihan dengan pemberian materi, pendampingan serta evaluasi penerapan buku ini dalam asuhan keperawatan. Hasil yang didapat pengetahuan dan ketrampilan perawat meningkat dalam penggunaan buku SDKI, SLKI dan SIKI.
\end{abstract}

Kata kunci: Dokumentasi keperawatan, SDKI, SLKI, SIKI

\begin{abstract}
Nursing documentation is a description of the actions given by nurses to patients in nursing care. This documentation consists of assessment, nursing diagnosis, intervention and evaluation. Nursing documentation should be evaluated in relation to its application in providing nursing care. There is still diversity in formulating nursing diagnoses due to the variety of nursing education, knowledge of nurses, and even differences in the reference standards used. Nurses at Charlie Hospital have different backgrounds from different educational institutions. So that training is needed in providing nursing care, especially in the formulation of nursing diagnoses. The purpose of this service is to increase knowledge, skills and the application of the SDKI, SLKI and SIKI books in the preparation of nursing documentation. This service method is by collecting information related to nurses' knowledge about the application of the SDKI, SLKI and SIKI, training by providing materials, mentoring and evaluating the application of this book in nursing care. The results obtained that the knowledge and skills of nurses increased in the use of the SDKI, SLKI and SIKI books.
\end{abstract}

Keywords: Nursing documentation, SDKI, SLKI, SIKI

Submitted: 20-04-2021, Revised: 18-08-2021, Accepted: 08-09-2021 


\section{Pendahuluan}

Dokumentasi keperawatan merupakan salah satu wujud bukti kinerja perawat. Diagnosis yang didokumentasikan dalam proses asuhan keperawatan masih perlu dievaluasi, karena masih adanya keragaman dalam merumuskan masalah yang disebabkan beragamnya pendidikan keperawatan, pengetahuan perawat, bahkan perbedaan standar acuan yang digunakan. Berdasarkan hasil wawancara dengan satu perawat di Charlie Hospital bahwa perawat belum menerapkan diagnosis keperawatan berdasarkan SDKI (Standar Diagnosis Keperawatan Indonesia), SLKI (Standar Luaran Keperawatan Indonesia) dan SIKI (Standar Intervensi Keperawatan Indonesia). Hasil pengkajian pada hari pertama pengabdian ini, bahwa perawat belum pernah mendapatkan pelataihan penerapan buku SDKI, SLKI dan SIKI, sehingga belum dapat di terapkan di rumah sakit. Hasil pengamatan dan pendampingan pengisian dokumentasi keperawatan, masih banyak ditemukan perawat yang belum mengetahui standar dokumentasi keperawatan. Maka dari itu peran pendampingan dalam melatih perawat dalam hal pengisian dokumentasi keperawatan sangat penting, sehingga dapat meningkatkan pengetahuan serta kualitas perawat dalam pengisian dokumentasi keperawatan (Hendriana dan Pranatha, 2020).

Dokumentasi keperawatan merupakan kewajiban yang harus dilakukan oleh perawat sebagai bukti penilaian kinerja perawat. Dokumentasi keperawatan merupakan wujud kualitas yang diberikan perawat dalam memberikan asuhan keperawatan untuk perkembangan proses profesionalisasi keperawatan. Dokumentasi keperawatan ini terdiri dari merumuskan diagnosis keperawatan, membuat luaran dan menyusun intervensi atau rencana tindakan keperawatan. Perihal ini dapat menimbulkan permasalahan berarti untuk praktisi keperawatan dalam pendokumentasian asuhan keperawatan kepada pasien (Hia, 2019). Hasil penelitian di RS X Jakarta terkait dokumentasi keperawatan menunjukkan kelengkapan dokumentasi keperawatan belum penuhi standar asuhan keperawatan Depkes yaitu $80 \%$ sehingga mencerminkan kualitas pelayanan keperawatan yang masih rendah (Maryam, 2015). Kelengkapan dokumentasi sangat dibutuhkan dalam proses keperawatan. Apalagi ada pergeseran dalam pendokumentasian keperawatan di Indonesia yang sebelumnya memakai NANDA (North American Nursing Diagnosis Association) sekarang sudah beralih pada SDKI (Standar Dokumentasi Keperawatan Indonesia). Peralihan penggunaan ini dalam pendokumentasian keperawatan dibutuhkan pelatihan untuk perawat dalam penyusunan dokumentasi keperawatan dengan SDKI, SLKI dan SIKI. Hal ini didukung oleh penelitian Maryam terkait perawat yang pernah mengikuti pelatihan akan melengkapi dokumentasi keperawatannya sebesar 59,3\% dibandingkan dengan perawat yang tidak pernah mengikuti pelatihan dokumentasi keperawatan (Maryam, 2015). Pendokumentasian keperawatan berdasarkan pengkajian keperawatan di RSUD Kabupaten Mamuju kategori kurang lengkap 97,8\%, diagnosis keperawatan masih ada kurang lengkap $(48,4 \%)$, perencanaan keperawatan masih ada kategori kurang lengkap (49,5\%), implementasi keperawatan kategori lengkap 52,7\%, dan evaluasi keperawatan masuk dalam kategori relevan $67,7 \%$. Hal ini perlu adanya pelatihan tentang asuhan keperawatan secara berkesinambungan sehingga perawat mampu meningkatkan pemahaman asuhan keperawatan dengan baik dan benar, bagi perawat yang mempunyai masa kerja masih baru maupun yang sudah lama (Supratti dan Ashriady, 2018). Perawat yang berpendidikan DIII Keperawatan mendokumentasikan asuhan keperawatan secara lengkap sebesar 58,6\% dibanding dengan yang berpendidikan SPK $(36,4 \%)$ (Maryam, 2015). Tingkat pendidikan perawat mempengaruhi pengetahuan perawat, dalam cara pandang perawat. Hal ini berdampak pada perilakunya terhadap kemampuannya dalam pengisian dokumentasi keperawatan yang berkualitas (Hendriana dan Pranatha, 2020). Berdasarkan latar belakang 
di atas menunjukkan bahwa permasalahan utama yang dihadapi mitra adalah: (a) Bagaimana penerapan diagnosis keperawatan berdasarkan SDKI. (b) Bagaimana menerapkan luaran berdasarkan SLKI (c) Bagaimana menerapkan intervensi berdasarkan SIKI. Karena itu, tim pelaksana pengabdian kepada masyarakat fokus pada penerapan diagnosis keperawatan, luaran yang diharapkan dan intervensi yang diberikan dalam mengelola asuhan keperawatan. 


\section{Metodologi}

Peserta dalam kegiatan ini sebanyak 15 perawat. Sebelum pelaksanaan kegiatan pengabdian, tim melakukan wawancara dengan hasil bahwa perawat belum pernah mendapatkan sosialisasi atau pelatihan tentang penggunaan buku SDKi, SLKI dan SIKI untuk membuat dokumentasi keperawatan. Oleh karena itu tim melaksanakan program pelatihan selama tiga bulan dari proses pengambilan data sampai evaluasi kegiatan. Pendidikan perawat DIII keperawatan sebanyak 12 orang dan Ners sebanyak 3 orang. Metode yang digunakan sebagai berikut:

a. Pengumpulan data

Penggalian informasi terkait dengan tingkat pengetahuan perawat terkait penggunaan buku SDKI, SLKI dan SIKI dengan dilakukan pre test.

b. Pelatihan

Metode pelatihan berfungsi untuk menyampaikan teori dan konsep yang sangat prinsip dan penting untuk dimengerti serta dikuasai oleh peserta pengabdian dilakukan secara daring Pelatihan diberikan selama tiga hari berupa pemberian materi tentang penggunaan buku SDKI, SLKI dan SIKI. Selesai pelatihan diberikan post test

c. Pendampingan

Pendampingan terhadap perawat dalam melakukan pendokumentasian. Kegiatan ini dilakukan selama satu bulan.

d. Evaluasi

Kegiatan terakhir dari pengabdian ini adalah mengevaluasi pengetahuan dan keterampilan dalam penerapan buku SDKI, SLKI dan SIKI. Evaluasi dilakukan dengan dilakukan pengamatan secara langsung terhadap dokumentasi yang sudah dilakukan perawat.

Bahan yang diperlukan dalam pengabdian ini yaitu internet yang memadai untuk dilakukan pelatihan secara daring, peserta diminta untuk menyiapkan buku SDKI (Standar Diagnosis Keperawatan Indonesia), SLKI (Standar Luaran Keperawatan Indonesia) dan SIKI (Standar Intervensi Keperawatan Indonesia) sebagai acuan pelatihan.

\section{Hasil dan pembahasan}

Sebelum dimulainya kegiatan pengabdian ini peserta diberikan ujian tes tulis terlebih dahulu sebelum pelatihan dimulai untuk mengetahui tingkat pengetahuan terkait dengan diagnosis keperawatan, luaran dan intervensi keperawatan sesuai dengan buku SDKI, SLKI dan SIKI. Sesudah pelatihan selesai peserta diberikan post test untuk menilai tingkat keberhasilan yang sudah dicapai dalam kegiatan pengabdian ini. Pengabdian ini terdiri dari penilaian tingkat pengetahuan dan keterampilan dalam penerapan SDKI, SLKI dan SIKI. 


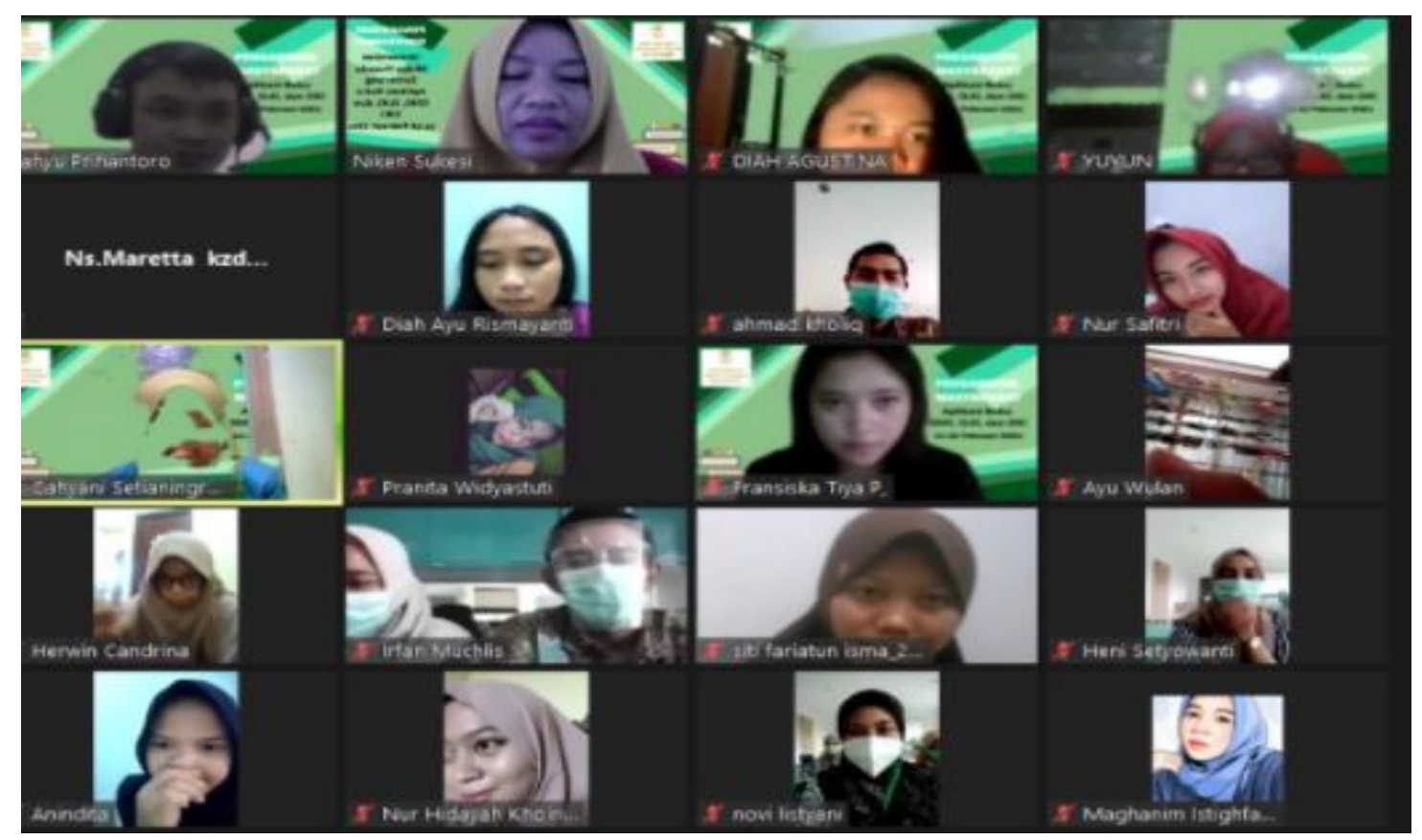

Gambar 1. Pemberian Materi secara Daring

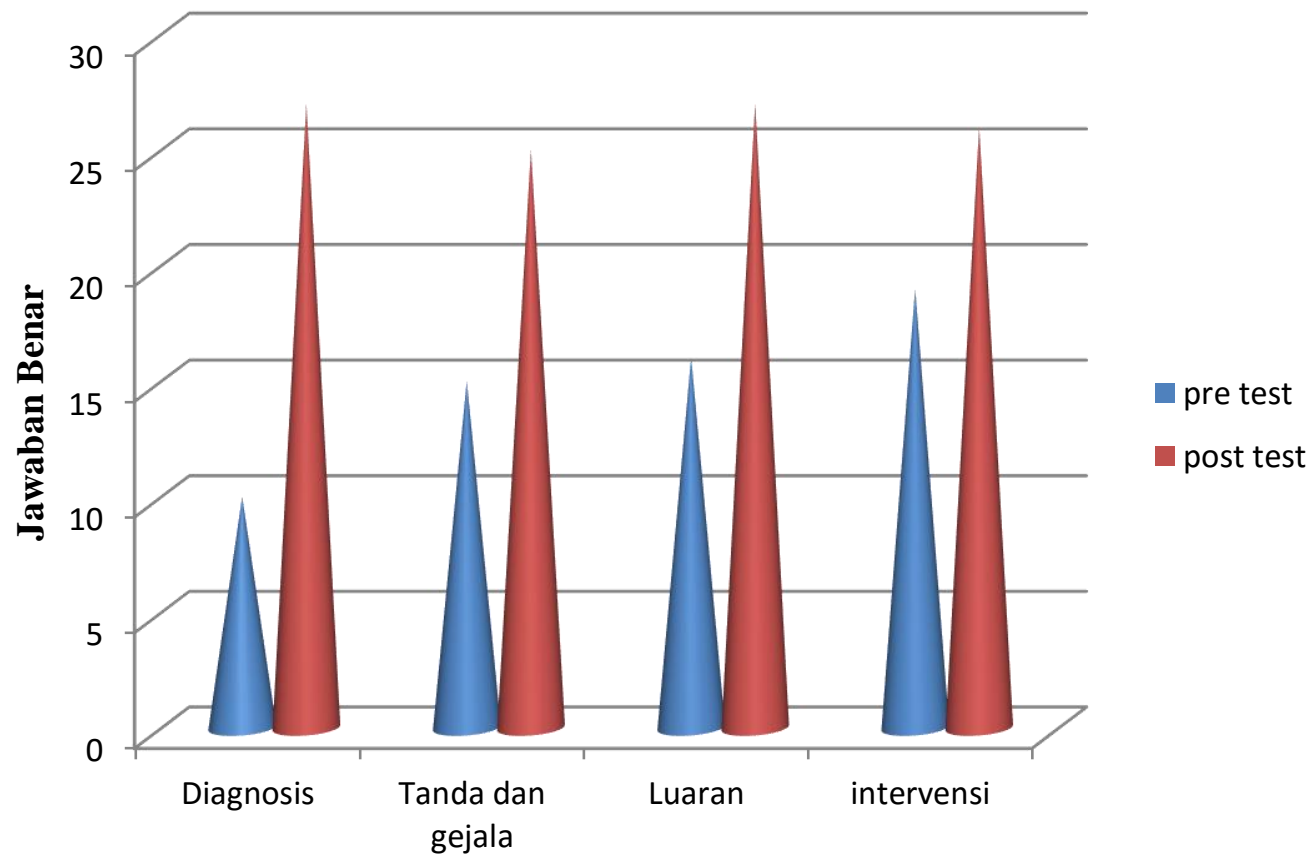

Pertanyaan

Gambar 2. Nilai Pengetahuan Sebelum dan Sedudah Pelatihan Penerapan Buku SDKI, SLKI dan SIKI 


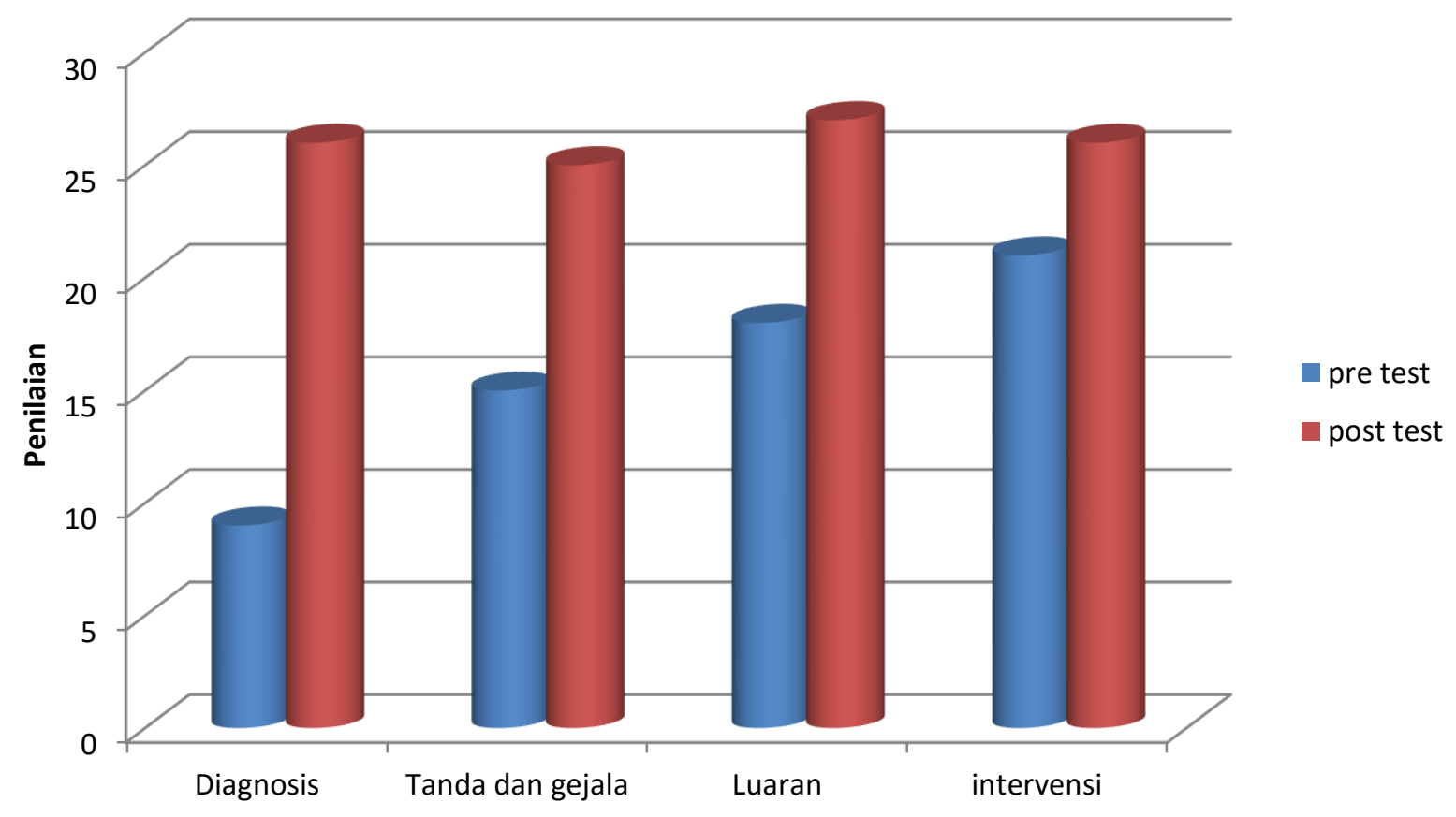

Observasi Ketrampilan

Gambar 3. Hasil Observasi Ketrampilan Sebelum dan Sesudah Pelatihan Penerapan Buku SDKI, SLKI dan SIKI

Berdasarkan gambar 2 dan 3 didapatkan hasil bahwa selama pelatihan dan pendampingan terjadi peningkatan pengetahuan dan ketrampilan perawat dalam membuat dokumentasi keperawatan. Hal ini dapat di lihat dari hasil evaluasi yang telah dilakukan setelah pelatihan dan pendampingan berakhir. Pelatihan ini dilakukan sebanyak 3 kali dengan dilakukan bimbingan dalam penyusunan dokumentasi sekaligus diberikan kasus pemicu untuk dianalisis oleh peserta pengabdian. Kasus pemicu ini diperuntukan supaya peserta dapat menyusun dokumentasi dengan berbagai diagnosis yang muncul serta berbagai intervensi yang harus ditetapkan, selain itu supaya memahami berbagai macam kasus yang muncul. Dengan diberikannya berbagai kasus pemicu, hasil pengetahuan dan keterampilan peserta meningkat. Pendampingan dan Pelatihan yang sudah diberikan dapat mengembangkan perawat bekerja secara efektif dan efisien, termasuk meningkatkan kemampuan dalam pendokumentasian asuhan keperawatan (Mailani \& Ramadini, 2019). Pelatihan ronde keperawatan (dokumentasi keperawatan) telah memberikan implikasi terhadap peningkatan keingintauan, maupun keterampilan dalam pemberian asuhan keperawatan sehingga intervensi atau pelatihan ronde keperawatan (dokumentasi) menghasilkan kinerja perawat yang semakin baik dalam pemberian asuhan keperawatan (Simamora, et al., 2017).

\section{Simpulan}

Pengaruh kegiatan pengabdian yang dilakukan terhadap peningkatan pengetahuan dan ketrampilan perawat memberikan dampak perbaikan terhadap penyusunan dokumentasi keperawatan. Peningkatan pengetahuan dan ketrampilan ini dibuktikan dengan hasil pengamatan penyusunan dokumentasi keperawatan yang dibuat oleh perawat sudah menerapkan SDKI, SLKI dan SIKI. 


\section{Ucapan terima kasih}

Tim pelaksana menyampaikan terimakasih kepada Lembaga Pengembangan Penelitian dan Pengabdian Masyarakat (LPPM) Universitas Widya Husada Semarang yang telah memberikan dukungan pendanaan dan direktur Charlie Hospital yang mengijinkan untuk dilakukan pengabdian.

\section{Daftar pustaka}

Hendriana, Y., \& Pranatha, A. (2020). Standar nursing language berbasis nanda, noc, dan nic terhadap kualitas pengisian dokumentasi keperawatan. nurscope: Jurnal Penelitian dan Pemikiran Ilmiah Keperawatan, 5(2), 26. Https://doi.org/10.30659/nurscope.5.2.26-31

Mailani, F., \& Ramadini, I. (2019). Pedampingan Dan Pelatihan Pendokumentasian Keperawatan Di Puskesmas Lubuk Buaya Padang. Jurnal Abdimas Saintika, 1(1), 5-13.

Maryam, R. S. (2015). Faktor-faktor yang berhubungan dengan Kelengkapan Pendahuluan Metode. 18(1), 1-8.

Simamora, R. H., Bukit, E., Purba, J. M., \& Siahaan, J. (2017). Penguatan kinerja perawat dalam pemberian asuhan keperawatan melalui pelatihan ronde keperawatan di rumah sakit royal prima medan. Jurnal pengabdian kepada masyarakat, 23(2), 300-304.

Supratti, S., \& Ashriady, A. (2018). Pendokumentasian Standar Asuhan Keperawatan Di Rumah Sakit Umum Daerah Mamuju. Jurnal Kesehatan Manarang, 2(1), 44. Https://doi.org/10.33490/jkm.v2i1.13 